\title{
Article
}

\section{Teaching Research Integrity and Bioethics to Science Undergraduates}

\section{Julio F. Turrens}

\author{
Department of Biomedical Sciences, University of South Alabama, Mobile, AL 36688
}

Received March 29, 2005; Revised July 5, 2005; Accepted July 27, 2005

\begin{abstract}
Undergraduate students in the Department of Biomedical Sciences at the University of South Alabama, Mobile, are required to take a course entitled "Issues in Biomedical Sciences," designed to increase students' awareness about bioethical questions and issues concerning research integrity. This paper describes the main features of this course and summarizes the results of a survey designed to evaluate the students' perceptions about the course. A summary of this study was presented at the 2002 Conference on Research Integrity in Potomac, MD, sponsored by the Office of Research Integrity of the National Institutes of Health.
\end{abstract}

Keywords: bioethics, research integrity, undergraduate education

\section{INTRODUCTION}

In his book entitled The Right Thing To Do, James Rachels states that "a mutually cooperative society can exist only if we adopt certain rules of behavior - rules that require telling the truth, keeping our promises, respecting one another's lives and property and so on" (Rachels, 2003a). Unless we adopt these types of rules, the resulting loss in trust will undermine and ultimately destroy the social fabric.

The college setting provides an excellent environment for a discussion of the principles behind moral reasoning, which in turn helps undergraduates acquire tools to address ethical issues in professional life. However, undergraduate science majors are seldom exposed to courses addressing ethical questions and principles.

Undergraduates in the Biomedical Sciences Program at the University of South Alabama, Mobile, are required to take a two-credit-hour senior-level course called "Issues in Biomedical Sciences" designed to expose students to current bioethical issues and raise their awareness concerning responsible conduct of research. Students who have taken formal bioethics courses earlier in their careers may request to be exempted from taking this course. The course is offered in the senior year because we want students to have completed a course in molecular biology (also a required course in our curriculum). The reason for this prerequisite is that we want students to be familiar with some of the techniques required for procedures that may pose bioethical questions (e.g., gene cloning, gene therapy, genetic diseases,

DOI: $10.1187 /$ cbe.05-03-0068

Address correspondence to: Julio F. Turrens (jturrens@usouthal. edu). genetic modification of existing organisms). In addition, in their senior year, students are familiar with each other as well as comfortable with the instructors since they have had other courses with them. These two factors further contribute to the success of the course.

Over the years, we have found that this course, through an informal process of open discussions and evaluation of various bioethical questions, has helped students become aware of current problems and taught them to ponder controversial issues. This paper describes the course rationale and presents the results of an anonymous and voluntary survey completed by students at the end of the course, in which they were asked to evaluate the course and what impact it had on them. The data were collected over a 3-yr period. We felt that it was important to make the survey voluntary and anonymous to give students freedom to participate or not in the course evaluation. In other words, if they did not feel comfortable answering some of these questions, we thought it was better not to force them to do so. For the same reason, we did not ask students to complete these questionnaires in class, thus avoiding the perception that some of their peers could see their answers.

\section{METHODS}

The impact of the course was evaluated by giving the students a survey on the last day of class, to be completed in private and dropped in the author's mailbox without any identifiers in order to maintain confidentiality. The survey consisted of a list of 14 statements, in no particular order, to which students were asked to assign a numeric value on a scale of 1-5, as follows: 1) strongly agree, 2) somewhat agree, 3) no opinion, 4) somewhat disagree, and 5) strongly 
Table 1. Examples of topics covered in "Issues in Biomedical Sciences" $a$

- What is morality? Ethical dilemmas. Looking at both sides.

- Cultural relativism.

- Student presentation: Should truth-telling depend on the patient's culture?

- Student presentation: Can family interests ethically outweigh patient autonomy?

- Simple subjectivism and emotivism. Listening to the real arguments on a specific issue.

- The Nuremberg laws of 1935. The "slippery slope."

- Human experimentation during World War II. Examples from Germany and Japan. Unit 731.

- The Nuremberg code, the Declaration of Helsinki, and the Belmont report.

- Papers on eugenics in the United States: "Social Control of the Congenital Defective," "Exoneration of the Feebleminded."

- California and Canadian sterilization laws.

- Unfounded medical treatments: lobotomy, blood and urine injections.

- What is the role of institutional review boards (IRBs)? Recent problems at Duke University, Fred Hutchinson, and Johns Hopkins.

- The Tuskegee syphilis study. Human radiation studies in the United States. Violations of informed consent. Vaccination for the Gulf War. Gene therapy.

- Student presentations: Placebos. Recent changes to the Declaration of Helsinki. Ethical aspects and current debates. AIDS study in Thailand and Uganda. Arthroscopy.

- Ethics in research. Office of Research Integrity. Examples of scientific misconduct. University of South Alabama policy on misconduct.

- Ethics in college: plagiarism. Cheating.

- Morality and religion.

- Psychological and ethical egoism.

- Utilitarianism.

- Student presentation: Advance directives. Cases that could have been prevented with living wills and court rulings.

- Kant and the absolute moral rules. Social contract.

- Organ transplantation. International market for body parts. China's death row inmates.

- Patenting genes. Human Genome Project.

- Student presentation: Insurance companies and genetic information.

- Student presentation: Misuse of technologic advances: designing infective organisms and bioterrorism.

- Medical advances and dilemmas. Prenatal diagnosis and eugenics.

- In vitro fertilization: Do unused embryos have rights?

- Student presentation: What do we do with unused embryos? Should we use them as sources of human stem cells, or should this research be banned?

- What makes us abuse others? Stanford prison experiment and torture in Iraq.

- Elements of a moral theory.

${ }^{a}$ This particular syllabus corresponds to the course taught in the fall semester of 2004. Although some topics may change from semester to semester, the outline of the course is basically the same.

disagree. The five answers were grouped in three categories (agree, no opinion, and disagree), and the percentage of students in each group having a better perception of the overall feeling concerning these statements was calculated. A total of $53 \%$ of the students (74 of 139) returned the surveys.

The survey was approved by the Institutional Review Board at the University of South Alabama in the fall of 2000 before being distributed to students.

\section{Course Description}

The course was designed to encourage students to read and openly discuss a variety of topics for every session (Table 1). The course was taught in an informal setting in which participants were encouraged to express their opinions and evaluate opposing viewpoints and alternative ideas, with the understanding that all discussions and comments would be kept confidential and not shared outside the classroom. The class size was limited to about 20 students per semester, and attendance was mandatory. Students missing a session for a valid reason had to write a one- to two-page summary of the readings for that particular session.

Part of the course was devoted to introducing students to various normative and meta-ethical theories (cultural relativism, emotivism, subjectivism, utilitarianism, social con- tract, and Kantianism). For these topics, students used a short textbook entitled The Elements of Moral Philosophy (Rachels, 2003b), which science majors (who do not have a strong background in philosophy) find very easy to read. The discussions were centered on pondering the limitations of each theory as well as its applicability to various situations. For example, cultural relativism stresses that it is important to recognize the intrinsic moral values within every culture. Yet, the theory has limitations: Many may find that it is morally wrong if some members within a culture compromise the dignity of other members of the same culture by imposing standards against their will (e.g., bigotry, racial segregation).

After discussing a specific ethical theory, students were asked to discuss examples of bioethical issues that fell within the scope of that theory. For example, the discussion of cultural relativism was followed by a discussion of recent articles, one of them describing the higher incidence of cervical cancer among Vietnamese women resulting from their reluctance to discuss with doctors what they may perceive as problems indicative of promiscuous behavior. Another article dealt with the increased number of aborted female fetuses in India and China, where there is a perception that it is more important to have sons than daughters. 
Table 2. Results from a survey designed to evaluate the impact of the course on our students ${ }^{a}$

\begin{tabular}{|c|c|c|c|}
\hline Statements & $\underset{(\%)}{\text { Agree }}$ & $\begin{array}{l}\text { No opinion } \\
(\%)\end{array}$ & $\begin{array}{l}\text { Disagree } \\
(\%)\end{array}$ \\
\hline $\begin{array}{l}\text { 1. My approach to thinking and dealing with ethical issues has changed as a result of } \\
\text { this course. }\end{array}$ & 81.1 & 4.1 & 14.9 \\
\hline $\begin{array}{l}\text { 2. I am better able to articulate my views concerning ethical issues as a result of this } \\
\text { course. }\end{array}$ & 82.4 & 8.1 & 9.5 \\
\hline 3. I was not aware of the variety of ongoing bioethical issues. & 67.6 & 8.1 & 24.3 \\
\hline 4. I already knew that cheating in college was a serious problem. & 75.7 & 8.1 & 16.2 \\
\hline $\begin{array}{l}\text { 5. I believe that in a competitive world, one may be forced to cheat or be a little un- } \\
\text { ethical in order to survive. }\end{array}$ & 35.1 & 9.5 & 55.4 \\
\hline $\begin{array}{l}\text { 6. Learning about the slippery-slope concept through a historical perspective (Nazi } \\
\text { Germany) helped me analyze current issues more objectively. }\end{array}$ & 77.0 & 16.2 & 6.8 \\
\hline 7. After taking this course, I find it more difficult to decide on an ethical issue. & 39.8 & 18.1 & 43.1 \\
\hline $\begin{array}{l}\text { 8. I may have cheated in the past without knowing that what I was doing was } \\
\text { wrong. }\end{array}$ & 41.4 & 18.6 & 40 \\
\hline 9. I cheated in the past even though I knew that what I was doing was wrong. & 46.0 & 13.5 & 40.5 \\
\hline $\begin{array}{l}\text { 10. The material presented in this course has helped prepare me for a professional ca- } \\
\text { reer. }\end{array}$ & 82.4 & 8.1 & 9.5 \\
\hline 11. I am less likely to indulge in unethical behavior as a result of this course. & 68.9 & 17.6 & 13.5 \\
\hline $\begin{array}{l}\text { 12. I am more likely to question my initial reactions when faced with an ethical dilem- } \\
\text { ma as a result of this course. }\end{array}$ & 86.5 & 5.4 & 8.1 \\
\hline $\begin{array}{l}\text { 13. Regardless of my initial opinion, I tend to look at both sides of an issue as a result } \\
\text { of this course. }\end{array}$ & 81.0 & 9.5 & 9.5 \\
\hline $\begin{array}{l}\text { 14. I have a better idea of what constitutes unethical behavior as a result of this } \\
\text { course. }\end{array}$ & 75.7 & 10.8 & 13.5 \\
\hline
\end{tabular}

${ }^{a}$ The survey consisted of a set of statements with which students were supposed to agree or disagree.

Similarly, after covering utilitarianism and Kantianism, we looked at how these principles relate to current legislation concerning organ donations in different countries. In order to provide more organs to patients waiting for a transplant, several countries have adopted the principle that all people are willing to donate their organs unless they explicitly refuse to do so (this is also known as presumed consent). In other countries, organ donors (or their family) must express their consent for organ donation before organs can be removed. In the first case, more organ recipients benefit at the expense of individual autonomy. In the second case, the principle of individual autonomy becomes a priority, regardless of whether more or fewer individuals receive an organ transplant.

We also brought attention to various historical events, which provided the background to understand the developments leading to current principles in the area of bioethics. In particular, we discussed the historical events that led to the holocaust in Europe, not from the traditional description of those atrocities, but rather from the perspective of exploring how a society may be manipulated and caught in a "slippery slope" that, in the end, leads them to commit those atrocities. In particular, we looked at some of the accepted ideas of the time (for example, social Darwinism) and compared ideas in vogue both in the United States and Germany concerning euthanasia and racial issues. For this part of the course, we used a required text entitled The Nazi Doctors and the Nuremberg Code (Annas and Grodin, 1992) and recommended various other books, including Factories of Death and Racial Hygiene (Harris, 1994; Proctor, 1988). Harris's book describes similar atrocities that took place in Unit 731 during the occupation of Manchuria (China) by Japan in World War
II. Finally, we discussed various equally disturbing examples of human experimentation that occurred in the United States (Beecher, 1966; Moreno, 1999) as well as examples of forced sterilization in the United States, Canada, and Sweden during the twentieth century.

From a didactic standpoint, there were many advantages that favored the introduction of ethical issues from a historical perspective. First, students were more objective when discussing a problem that occurred $70 \mathrm{yr}$ ago in Europe. It was important for students to explore how we, as humans, may accept (and even become part of) a repressive system, particularly when we are encouraged or empowered by the system to do so. Moreover, it was important to understand how quickly humankind can fall into an unprecedented level of human brutality. This point was supported during a study carried out in 1971 in the Department of Psychology at Stanford University (Haney and Zimbardo, 1998; Zimbardo, 2004). In this study, students volunteered to participate in an experiment in which they would portray the roles of prisoners or guards. The study was stopped less than a week after starting because, in a short time, the guards were abusing their power and humiliating those playing the role of prisoners. Recent examples of American soldiers torturing and humiliating prisoners in Iraq further stressed this point.

Addressing issues from a historical point of view also allowed students to see how these events led to major bioethical landmarks. First, we discussed the Nuremberg code at the end of World War II, which introduced the idea of informed consent and set legal definitions concerning the use of humans in science and research. This document was followed later on by the Helsinki accords and the Belmont 
report, which set the foundation and rules for research involving humans. It also became obvious why institutional review boards had to be created to scrutinize carefully the research protocols involving humans, protecting people when they become research subjects.

In this course, we also discussed issues and regulations concerning "Responsible Conduct of Research," starting from the definitions of what constitutes research misconduct and conflict of interest (Shamoo and Resnik, 2003). Students were informed of the role of university investigative committees as well as that of the Office of Research Integrity (National Institutes of Health) and the Office of the Inspector General (National Science Foundation) in overseeing the integrity of most of the federally funded research. Students also discussed issues of academic integrity, not only for professionals but also among their peers, and the increasing problem of cheating in college.

Throughout the course, we also explored current dilemmas resulting from advances in the sciences leading to new technologies that may have unexpected effects on our society. Some examples include how advances in molecular biology led to the recent chemical synthesis of the polio virus in vitro (Cello et al., 2002) and its implications on bioterrorism and how our knowledge of the human genome and the ability to detect mutations may have an impact on health insurance rates and coverage. Part of the information discussed in class was updated every semester through the use of articles in journals, newspapers, and the Internet. The printed sources of information included a compilation of bioethical articles (Levine, 2004), the journals Science, Nature, and the Hastings Center Report, and newspaper articles. Internet sources included "Science in the News" (daily, published by the scientific society Sigma Xi) and "The Scientist" (sent daily by The-Scientist.com) and daily summaries from various newspapers.

\section{Students' Evaluation}

The final course grade was a combination of various components. Ten percent of the grade came from participation and an oral presentation. For the oral presentations, students researched a topic from the syllabus and presented it to their peers. The weight of these presentations in the final grade was kept low to allow students to express themselves freely, without being concerned about the impact of their statements on their grade.

Fifteen percent of the grade resulted from 10 quizzes about daily readings, which were administered randomly throughout the semester to encourage students to read the materials assigned for a specific session. A quiz involved writing one or two sentences about the topic to be discussed in that session (for example, the main premises of an ethical theory, a brief description of a case, or the conclusions reached by the author of an article).

Another component of the course grade (40\%) came from a series of biweekly short papers (about 700 words) in which students expanded on any of the four topics covered during the previous $2 \mathrm{wk}$. As a final report, students wrote a six- to eight-page-long paper (35\% of the grade) on a topic of their choice, preferably not previously addressed in the course. For this article, they were required to research additional references, books, or Web sites to document their study and support their conclusions. A sample of topics chosen by students for their final report included surrogacy, sales of organs for transplantation, DNA fingerprinting in death penalty cases, gene therapy for the treatment of diseases versus the potential of gene transfer to implant specific traits in embryos, and alternatives to placebocontrolled studies.

In their writings, students were asked not only to express their opinions but also to objectively address both sides of controversial issues. They were expected to identify positive aspects of all perspectives, even if they disagreed with one particular viewpoint.

\section{Students' Perception and Feedback}

The perception of students concerning the course was evaluated through a survey (see Table 2). Some of the statements were designed to determine their perception concerning ethical issues, while others were more direct, addressing their attitude toward cheating in college.

They scored the statements on a scale of $1-5$, with 1 and 2 indicating agreement and 4 and 5, disagreement. In order to estimate the proportion of students who agreed or disagreed with a particular statement, we combined options 1 and 2 (agreement) and 4 and 5 (disagreement), assuming that those who marked option 3 did not have an opinion.

The course improved their awareness of current bioethical problems and issues concerning professional integrity. Over $80 \%$ of the students stated that the course helped them learn how to judge and interpret some of these problems and that they would be less prone to jump to conclusions (see question 13). At the same time, nearly $40 \%$ of the students indicated that, after taking this course, it was more difficult for them to make ethical decisions (question 7). We think that one of the reasons for this perceived difficulty is that the course taught them to evaluate and try to identify something positive about each side of an issue, which is something they were not accustomed to doing prior to taking this course. Thus, although it may have become more difficult to confront an ethical dilemma, the students felt better prepared to evaluate controversial problems in the future (questions 1 , 2,10 , and 14).

Undergraduates are usually unaware of the magnitude and variety of bioethical issues. Although their perception at the end of the course was quite positive, it is reasonable to ponder whether this perception will last or if it is just a result of the excitement brought about by these types of courses. Although we do not know the answer to this question, it is encouraging that some of my former students continue to contact me when they read or encounter problems that may be relevant to the course, even years after graduation.

\section{ACKNOWLEDGMENTS}

I want to thank Satya N. Mishra, Professor of Mathematics and Statistics, for his helpful comments concerning data analysis.

\section{REFERENCES}

Annas, G.J., and Grodin, M.A. eds. (1992). The Nazi Doctors and the Nuremberg Code. New York: Oxford University Press.

Beecher, H.K. (1966). Ethics and clinical research. N. Engl. J. Med. $274,1354-1360$ 
Cello, J., Paul, A.V., and Wimmer, E. (2002). Chemical synthesis of poliovirus cDNA: generation of infectious virus in the absence of natural template. Science 297, 1016-1018.

Haney, C., and Zimbardo, P. (1998). The past and future of U.S. prison policy: twenty-five years after the Stanford Prison Experiment. Am. Psychol. 53, 709-727.

Harris, S. (1994). Factories of Death. New York: Routledge.

Levine, C. (2004). Taking Sides: Current Issues in Bioethics, 10th ed. New York: McGraw-Hill.

Moreno, J. (1999). Undue Risk: Secret State Experiments on Humans. New York: Freeman.
Proctor, R. (1988). Racial Hygiene: Medicine under the Nazis. Cambridge, MA: Harvard University Press.

Rachels, J. (2003a). The Right Thing To Do, 3rd ed. New York: McGraw-Hill.

Rachels, J. (2003b). The Elements of Moral Philosophy, 4th ed. New York: McGraw-Hill.

Shamoo, A., and Resnik, D. (2003). Responsible Conduct of Research. New York: Oxford University Press.

Zimbardo, P.G. (2004). A situationist perspective on the psychology of good and evil: understanding how good people are transformed into perpetrators. In: The Social Psychology of Good and Evil, ed. A.G. Miller. New York: Guilford Publications, 21-50. 